\title{
EFEKTIFITAS PERKULIAHAN DENGAN ZOOM CLOUD MEETING MASA PANDEMI COVID-19 PADA PEMAHAMAN KONSEP TERMODINAMIKA
}

\author{
Syahrial Ayub*, Muhammad Taufik, Aris Doyan, Sutrio \\ Pendidikan Fisika FKIP Universitas Mataram \\ *Corresponding Author: syahrial_ayub@unram.ac.id
}

\section{Article History}

Received : March 22 $2^{\text {th }}, 2021$

Revised : March 30 ${ }^{\text {th }}, 2021$

Accepted : April 04 ${ }^{\text {th }}, 2021$

Published : May 09 $9^{\text {th }}, 2021$

\begin{abstract}
Termodinamika adalah salah satu matakuliah yang mengharuskan penjelasan oleh dosen, karena tingkat kesulitannya. Pandemi Covid-19 memaksa perkuliahan dilaksanakan secara daring dan tidak memungkinkan dilakukan tatap muka di kelas. Salah satu alternatifnya adalah dengan menggunakan aplikasi zoom cloud meeting. Tujuan penelitian adalah menentukan keefektifan penggunaan aplikasi zoom cloud meeting pada perkuliahan termodinamika di program studi pendidikan fisika Universitas Mataram. Kegiatan ini dilakukan pada 29 mahasiswa semester IV kelas A semester genap tahun 2019/2020 dengan menggunakan desain one group pretest-posttest. Kemampuan pemahaman konsep termodinamika diukur menggunakan instrumen tes objektif sebanyak 25 item. Instrumen tes yang digunakan telah teruji validitas dan reliabilitasnya. Data pemahaman konsep termodinamika dianalisis secara statistik dengan melakukan uji normalitas, uji homogenitas, dan uji-t paired (paired t-test). Hasil penelitian menunjukkan penggunaan zoom cloud meeting pada perkuliahan termodinamika efektif dalam menanamkan konsep termodinamika. Berdasarkan hasil penelitian ini, direkomendasikan sebaiknya perkuliahan selama pandemi Covid-19 dilaksanakan secara tatap muka dengan zoom cloud meeting, terutama untuk materi-materi yang mempunyai tingkat kesulitan yang tinggi dan butuh penjelasan.
\end{abstract}

Keywords: Efektifitas perkuliahan, Penggunaan zoom cloud meeting, pemahaman konsep termodinamika.

\section{PENDAHULUAN}

Termodinamika adalah matakuliah yang mempelajari perubahan panas menjadi kerja untuk dapat dimanfaatkan bagi kesejahteraan manusia. Materi termodinamika diperkuliahan sarjana berhubungan dengan delapan variabel seperti tekanan (p), suhu $(T)$, volume $(V)$, energi dalam (u), entalpi (h), entropi (s), fungsi Gibbs (G) dan fungsi Helmhotz (F) (Ayub, S.,2020). Hubungan-hubungan kedelapan varibel ini akan mendapatkan persamaan energi yang dibutuhkan dalam pengembangan ilmu ini. Persamaan persamaan didapatkan dengan turunan differensial, integral dan pemecahan persamaan orde satu atau dua. Hal ini merupakan suatu yang agak sulit bagi mahasiswa, olehkarena itu perkuliahan ini termasuk pada jenis perkuliahan yang membutuhkan penjelasan dan bimbingan dosen serta dilakukan dengan tatap muka di depan kelas. Saat ini, masih pada masa pandemi covid-19. Perkuliahan di program studi pendidikan fisika Universitas Mataram masih dilaksanakan dari rumah. Banyak pilihan metode mengajar secara online yang dapat menjadi alternatif pilihan perkuliahan oleh dosen. Salah satunya menggunakan aplikasi meeting online dengan konsep screen sharing. Aplikasi ini memungkinkan penggunanya bertatap muka dengan lebih dari 100 orang partisipan. Tidak hanya di PC atau laptop, aplikasi ini juga bisa diunduh di smartphone yang dinamakan zoom clouds meeting (Tekno, 2020). Zoom Meeting sendiri merupakan sebuah media pembelajaran menggunakan video. Pendiri aplikasi Zoom Meeting yaitu Eric Yuan yang diresmikan tahun 2011 yang kantor pusatnya berada di San Jose, California . Aplikasi ini tidak hanya digunakan untuk pembelajaran saja tetapi bisa digunakan untuk urusan perkantoran maupun urusan lainnya. Platfrom ini gratis jadi dapat digunakan oleh siapapun dengan batas waktu empat puluh menit dan tidak ada batasan waktu jika akun kita berbayar. Dalam aplikasi Zoom Meeting ini kita bisa berkomunikasi langsung dengan siapapun lewat video. Oleh karena itu, memang cocok digunakan sebagai media 
perkuliahan. Jadi, menggunakan aplikasi ini perkuliahan dilakukan dengan tatap muka langsung dengan mahasiswa, dosen juga bisa mengirim white board dan dapat ditulis selayaknya papan tulis di kelas, dosen juga dapat mengirimkan power point, atau terhubung langsung dengan software yang dibutuhkan serta internet. Aplikasi ini, memungkinkan interaksi antara dosen dengan mahasiswa seperti halnya mengajar di kelas secara normal. Aplikasi ini juga bisa di setting untuk kerja kelompok. Dosen dapat mengelompokkan mahasiswa sesuai kelompoknya dan mereka bisa berdiskusi bersama secara online sebelum mereka presentasi. Penelitian ini bertujuan untuk mengetahui efektifitas Zoom Clouds Meeting terhadap pemahaman konsep termodinamika. Dalam kegiatan perkuliahan online dengan memanfaatkan penggunaan aplikasi Zoom Clouds Meeting, terdapat dua buah teori yang dapat meninjau kegiatan pembelajaran tersebut. Teori behavioristik merupakan salah satu teori yang membahas tentang berubahnya perilaku seseorang yang didasari dari sebuah pengalaman. Teori behavioristik menekankan terbentuknya perilaku yang terlihat dari hasil proses belajar (Klinger, 1997). Lalu, terdapat juga teori kognitif. Di dalam sebuah teori kognitif, tingkah laku individu dapat diarahkan melalui sudut pandang individu tersebut dan juga pengalamannya dalam situasi yang memiliki relasi dengan sebuah tujuan. Karena, dalam tingkah laku individu sifatnya dinamis. Sifat dinamis tersebutlah yang dipengaruhi oleh proses belajar (Mulya, 2020). Teori komunikasi pendidikan juga menjadi sebuah landasan dalam penelitian ini. Karena dalam proses pembelajaran tentunya melakukan proses komunikasi. Komunikasi yang dilakukan mahasiswa dengan dosen atau mahasiswa dengan mahasiswa lainnya. Dalam penelitian ini, apakah pemanfaatan aplikasi Zoom Clouds Meeting efektif dalam proses perkuliahan atau tidak serta dapat meningkatkan pemahaman konsep termodinamika. Manfaat dilakukan penelitian ini ialah untuk mengetahui dampak dan tanggapan setiap mahasiswa yang sedang menjalani pendidikan di program studi pendidikan fisika terhadap pembelajaran jarak jauh menggunakan aplikasi Zoom Clouds Meeting. Harapannya penelitian ini dapat memberikan gambaran kepada dosen, mahasiswa dan pendidik lainnya tentang aplikasi Zoom Clouds Meeting, sehingga dapat menjadi alternatif perkuliahan di masa pandemi covid-19 ini.

\section{METODE}

Teknik yang digunakan pada penelitian ini adalah jenis eksperimen semu (quasiexperimental) dengan one group pretest-posttest design (Fraenkel et al., 2012). Pada penelitian ini hanya ada satu kelompok sampel yang diberikan perlakuan (treatment) perkuliahan dengan menggunakan aplikasi zoom clouds meeting. Sampel ditentukan dengan cara sampel bertujuan (purposive sampling), yaitu 29 mahasiswa semester IV tahun 2019/2020 dengan termodinamika. Data pemahaman konsep termodinamika dikumpulkan menggunakan instrumen tes berbentuk soal objektif sebanyak 25 item soal yang disusun mengacu pada konsep termodinamika, yaitu sistem termodinamika, persamaan keadaan, turunan parsial dalam termodinamika, hukum pertama termodinamika dan beberapa akibat dari hukum pertama termodinamika (Ayub, S.,2020). Sebelum diterapkan (implementasi kan), instrumen tes diuji validitas, reliabilitas, daya beda dan indek kesukarannya. Menghitung indeks kesukaran untuk setiap item menggunakan rumus (Slameto, 2010).

$$
D=\frac{R_{u}+R_{L}}{N_{u}+N_{L}}
$$

dimana, $\mathrm{D}$ indeks kesukaran setiap item; $\mathrm{R}_{\mathrm{u}}$ jumlah jawaban yang benar dari item yang bersangkutan kelompok atas; $\mathrm{R}_{\mathrm{L}}$ jumlah jawaban yang benar dari item yang bersangkutan kelompok bawah; $\mathrm{N}_{\mathrm{u}}$ jumlah mahasiswa yang termasuk 27\%-33,3\% kelompok atas, dan $\mathrm{N}_{\mathrm{L}}$ jumlah mahasiswa yang termasuk 27\%-33,3\% kelompok bawah. Kriteria penilaiannya adalah:

Tabel 1: Kategori penilaian indeks kesukaran

\begin{tabular}{cc}
\hline Rentang Skor & Kategori \\
\hline $0-0,1$ & terlalu sukar \\
$0,1-0,2$ & amat sukar \\
$0,2-0,4$ & sukar \\
$0,4-0,7$ & sedang \\
$0,7-0,9$ & mudah \\
$0,9-1$ & amat mudah \\
\hline
\end{tabular}

Indeks pembeda soal bertujuan mengetahui daya 
beda suatu soal. Indeks ini juga mampu membedakan mahasiswa yang pintar dan kurang pintar. Daya beda item ini, ditentukan dengan rumus (Slameto, 2010) :

$$
V=\frac{R_{u}-R_{L}}{N_{u}}
$$

Sebuah item dikatatan valid, bila item itu dapat tepat mengukur apa yang hendak diukur. Validitas item ditentukan dengan rumus:

$$
\gamma_{p b i}=\frac{M_{p}-M_{t}}{S_{t}} \sqrt{\frac{p}{q}}
$$

dimana, $\gamma_{p b i}$ koefisien korelasi biserial; $\mathrm{M}_{\mathrm{p}}$ rerata skor dari mahasiswa yang benar bagi item yang dicari validitasnya; $\mathrm{M}_{\mathrm{t}}$ rerata skor total; $\mathrm{S}_{\mathrm{t}}$ standar deviasi; p proporsi mahasiswa yang menjawab benar, dan $\mathrm{q}$ adalah proporsi mahasiswa yang menjawab salah.

Tabel 2: Kategori penilaian validitas

\begin{tabular}{cc}
\hline Rentang Skor & Kategori \\
\hline $0,8-1,0$ & Sangat tinggi \\
$0,6-0,8$ & Tinggi \\
$0,4-0,6$ & Cukup \\
$0,2-0,4$ & Rendah \\
$0,0-0,2$ & Sangat rendah \\
\hline & (Arikunto, S., 2006)
\end{tabular}

Mengukur reliabilitas item menggunakan rumus Kuder Ricardson (KR-20) yaitu:

$$
r=\frac{n}{n-1}\left(\frac{S^{2}-\sum p q}{S^{2}}\right)
$$

dimana, $\mathrm{r}$ adalah reliabilitas item; $\sum p q$, jumlah hasil perkalian antara $\mathrm{p}$ dan $\mathrm{q}$; dan $\mathrm{n}$ adalah jumlah item.

Tabel 3: Kategori penilaian reliabilitas

\begin{tabular}{cc}
\hline Rentang Skor & Kategori \\
\hline $0,8-1$ & Sangat tinggi \\
$0,6-0,8$ & Tinggi \\
$0,4-0,6$ & Cukup \\
$0,2-0,4$ & Rendah \\
$0,0-0,2$ & Sangat rendah \\
\hline & (Arikunto, S., 2006)
\end{tabular}

Pemberian nilai pada pretest dan posttest adalah dengan menggunakan skala 2, yaitu menjawab benar diberi skor 1 dan yang menjawab salah diberi skor 0. Jumlah item 25, jadi skor maksimal yang didapat adalah 25 dan skor minimal adalah 0. Menurut Hake, R. (1999), nilai Gain dihitung dengan persamaan:

$$
<g>=\frac{S_{\text {post }-} S_{\text {pre }}}{S_{\text {maks }} S_{\text {pre }}}
$$

Dimana, $<g>$ adalah skor N-Gain, $S_{\text {post }}$ adalah skor tes akhir $S_{\text {pre }}$ adalah skor tes awal dan $S_{\text {maks }}$ adalah akor maksimal.

Tabel 4 : Kriteria Skor N-Gain

\begin{tabular}{|c|l|}
\hline $\begin{array}{l}\text { Klasifikasi Skor } \\
\text { N-Gain }\end{array}$ & Kategori \\
\hline $0,7<\langle g\rangle \leq 1$ & Tinggi \\
\hline $0,3<\langle g\rangle \leq 0,7$ & Sedang \\
\hline$\langle g\rangle \leq 0,3$ & Rendah \\
\hline
\end{tabular}

Analisis data pretest dan posttest dianalisis secara statistik menggunakan uji-t (pair t-test) pada taraf signifikansi ( $p$-value) sebesar 0,05. Sebelumnya diuji normalitas sampel. Uji homegenitas dilakukan untuk meyakinkan uji hipotesis yang dilakukan. Hipotesis penelitian yang diuji, yaitu Ha (perkuliahan dengan menggunakan zoom clouds meeting efektif dalam menanamkan konsep termodinamika pada mahasiswa semester IV A tahun 2019/2020 di program studi pendidikan fisika Universitas Mataram), dan Ho (perkuliahan dengan menggunakan zoom clouds meeting tidak efektif dalam menanamkan konsep termodinamika pada mahasiswa semester IV A tahun 2019/2020 di program studi pendidikan fisika Universitas Mataram). Analisis secara statistik menggunakan alat bantu statistik SPSS 20,0

\section{HASIL DAN PEMBAHASAN}

\section{a) Hasil Penelitian}

a.1 N-Gain Pemahaman Konsep Termodinamika

Hasil pretest, posttest dan N-Gain pemahaman konsep termodinamika dari 29 mahasiswa semester IV tahun 2019/2020, disajikan pada grafik 1 di bawah ini: 


\section{Grafik-1 : Pretest, Posttest dan N-Gain}

Pemahaman Konsep Termodinamika

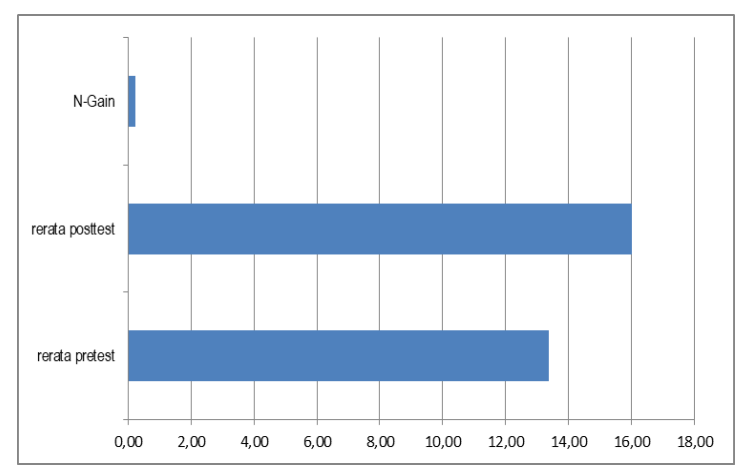

Grafik-1 menunjukkan rerata pretest 13,38 , rerata posttest 16,03 dan $\mathrm{N}$-Gain 0,24 yang artinya berada pada kategori rendah.

\section{a.2 Analisis Statistik Hasil Pretest-Posttest}

Analisis statistik dilakukan untuk mengetahui kefektifan penggunaan zoom clouds meeting pada perkuliahan termodinamika di program studi pendidikan fisika Universitas Mataram. Uji normalitas, uji-t dan uji homogenitas dilakukan dengan menggunakan SPSS 20,0. Uji paired t-test yang digunakan adalah uji beda parametris pada dua data yang berpasangan. Sesuai dengan pengertian tersebut, maka uji ini diperuntukkan pada uji beda atau uji komparatif rerata dua sampel berpasangan. Dua sampel yang dimaksud adalah sampel yang sama namun mempunyai dua data. Uji paired t-test merupakan bagian dari statistik parametrik, olehkarena itu sebagaimana aturan dari statistik parametrik data penelitian haruslah terdistribusi normal. Terdistribusi normal maksudnya skor pretest dan posttest mempunyai proporsi yang sesuai antara skor tinggi, sedang, dan rendah. Skor tidak terkosentrasi pada nilai tinggi saja, rendah saja, atau sedang saja. Uji normalitas Kolmogorov-Smirnov dapat dilihat pada tabel 5 berikut ini:

Tabel 5: Hasil uji normalitas pretest (Y01A) dan posttest (Y02A)

\begin{tabular}{|c|r|r|r|r|r|r|}
\hline & \multicolumn{3}{|c|}{ Kolmogorov-Smirnov } & \multicolumn{3}{|c|}{ Shapiro-Wilk } \\
\cline { 2 - 7 } & $\begin{array}{c}\text { Statisti } \\
\mathrm{C}\end{array}$ & $\mathrm{df}$ & Sig. & Statistic & $\mathrm{df}$ & Sig. \\
\hline Y01A & .112 & 29 & $.200^{*}$ & .981 & 29 & .862 \\
Y02A & .159 & 29 & .059 & .944 & 29 & .130 \\
\hline
\end{tabular}

Uji normalitas Kolmogorov-Smirnov merupakan bagian dari uji asumsi klasik yang bertujuan untuk mengetahui apakah nilai residual berdistribusi normal atau tidak. Model regresi yang baik adalah memiliki residual yang berdistribusi normal. Rumusan hipotesis pada uji normalitas adalah, Ho; nilai residual berdistribusi normal, dan $\mathrm{Hi}$; nilai residual tidak berdistribusi nomal. Dasar pengambilan kesimpulan, jika nilai signifikansi (sig.) $>0,05$ maka Ho diterima, Hi ditolak artinya nilai residual berdistribusi normal. Jika signifikansi (sig.) < 0,05 maka Hi diterima, Ho ditolak artinya nilai residual tidak berdistribusi normal. Hasil uji normalitas Kolmogorov-Smirnov menunjukkan nilai 0,200 dan 0,0589 lebih besar dari 0,05 , artinya pretest dan posttest pada penelitian ini berdistribusi normal. Setelah uji normalitas dilakukan, dilakukan uji paired t-test untuk mengetahui keefektifan penggunaan zoom clouds meeting pada perkuliahan termodinamika. Hasil uji paired ttest dapat dilihat pada tabel 6 berikut ini:

Tabel 6 : Hasil uji paired t-test pretest (Y01A) dan posttest (Y02A)

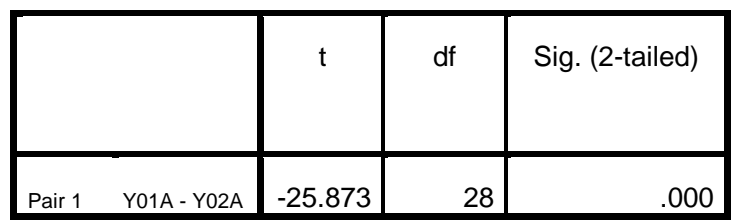

Dasar pengambilan keputusan hasil uji paired ttest adalah; 1) jika nilai Sig. (2-tailed) < 0,05, maka terdapat perbedaan yang signifikan antara pretest dan posttest; 2) jika nilai Sig. (2-tailed) > 0,05 , maka tidak terdapat perbedaan yang signifikan antara pretest dan posttest. Tabel 6 memperlihatkan nilai Sig. (2-tailed) 0,000 <0,05, maka dapat disimpulkan terdapat perbedaan yang signifikan antara pretest dan posttest pada perkuliahan termodinamika di program studi pendidikan fisika FKIP Universitas Mataram.

\section{b) Pembahasan}

b.1 N-Gain Pemahaman Konsep Termodinamika Uji N-Gain adalah sebuah uji yang bisa memberikan gambaran umum peningkatan skor hasil perkuliahan antara sebelum dan sesudah diterapkannya metode pada perlakuan yang diberikan dalam penelitian (Hake, R. R, 1999). 
Hasil penelitian menunjukkan N-Gain yang didapatkan adalah 0,24. Bila dikonsultasikan pada tabel 4, maka $\mathrm{N}$-Gain termasuk pada kategori rendah. Artinya terdapat peningkatan pemahaman konsep Termodinamika, tetapi peningkatannya tidak terlalu besar. Hal ini, kemungkinan disebabkan pemanfaatan aplikasi zoom cluod meeting belum optimal dan jaringan internet yang tidak stabil serta zoom free dibatasi 40 menit berikutnya disambungkan lagi. Banyak aplikasi zoom cloud meeting yang belum diterapkan pada perkuliahan oleh dosen dan mahasiswa sehingga mengurangi kualitas perkuliahan. Sebagai contoh, salah satu aplikasi yang jarang digunakan atau dilupakan adalah aplikasi yang bisa mengklasifikasikan mahasiswa sesuai kelompoknya masing-masing. Mahasiswa dapat bekerja dan berdiskusi di masing-masing kelompoknya sesuai dengan batas waktu yang diberikan dosen. Setelah itu mahasiswa dapat bergabung kembali pada kelas besar dan mempresentasikan hasil diskusi mereka. Kegiatan ini, persis seperti perkuliahan tatap muka di kelas. Kemudian zoom juga dibatasi waktunya 40 menit bagi yang free, ini jelas sangat mempengaruhi kualitas perkuliahan dengan waktu yang terbatas ini walaupun dapat disambungkan lagi dan kemungkinan penyebab yang lain adalah jaringan internet yang tidak baik sehingga mempengaruhi kualitas gambar, suara dan lainnya. Inilah beberapa kemungkinan yang menyebabkan $\mathrm{N}$-Gain pada penelitian ini masih pada kategori rendah. Semoga pada penelitianpenelitian selanjutnya dosen dapat memperhatikan faktor-faktor ini.

\section{b.2 Analisis Statistik Hasil Pretest-Posttest}

Hasil penelitian ini, menunjukkan penggunaan aplikasi zoom clouds meeting pada perkuliahan efektif dalam menanamkan konsep termodinamika mahasiswa semester IV tahun 2019/2020 program studi pendidikan fisika Universitas Mataram selama masa pandemi Covid-19. Temuan hasil penelitian ini, sejalan dengan beberapa studi sebelumnya di berbagai intsitusi pendidikan. Monica, J.,(2020) bahwa pembelajaran secara online menjadikan mahasiswa lebih mandiri dan mendorong mahasiswa untuk lebih aktif dalam perkuliahan. Hanya saja terdapat beberapa hal yang harus diperhatikan, salah satunya adalah ketersediaan paket internet yang baiayanya dikeluarkan secara lebih ekstra oleh mahasiswa saat pembelajaran online. Ismawati (2020), Pembelajaran online melalui zoom clouds meeting menjadikan pembelajaran lebih efektif, karena banyaknya fitur-fitur pendukung saat berlangsungnya pembelajaran online di tengah pandemi covid-19. Robandi (2020), perkuliahan secara online di kampus IPDN Sumatera Barat dilakukan dengan zoom clouds meeting lebih efesien dimasa pandemi covid-19. Perkuliahan dilaksanakan dengan mengumpulkan praja di satu kelas, dan dosen mengajar melalui zoom yang ditampilkan lewat proyektor. Arizona, K.,(2020) sistem pembelajaran online berbasis proyek memberikan banyak peluang untuk mengakses bahan ajar untuk warga pembelajar. Banyak platform maupun media online yang dapat diakses melalui jaringan internet oleh pengajar maupun peserta didik. Pembelajaran online berbasis proyek ini dapat dikombinasikan fiturnya. Rizaldi (2020), aplikasi zoom clouds meeting cukup efektif untuk media perkuliahan daring. Efektifitas yang dimaksud disini, yaitu efektifitas dalam segi waktu dan tempat, efektifitas volume pengguna dan efektifitas fasilitas (alat tulis, buku dan lainnya). Segi kendala yang muncul adalah jaringan internet yang kurang optimal, kuota internet yang besar untuk zoom clouds meeting, batas waktu free zoom clouds meeting yang hanya 40 menit dan lain sebagainya. Temuan penelitian ini, menjawab masalah utama perkuliahan di masa pandemi covid-19 ini. Perkuliahan dapat seperti yang sebenarnya tatap muka bisa dilakukan dengan menggunakan aplikasi zoom clouds meeting dengan mengoptimalkan fitur-fitur yang dipunyainya. Mahasiswa dapat merasakan nuansa kuliah seperti biasa tatap muka walaupun dilaksanakan secara online. Interaksi antara mahasiswa dan dosen juga bisa dilakukan seperti bertanya, menjawab, menulis di white board, presentasi, diskusi kelompok dan lainnya. Olehkarena itu berdasarkan penelitian ini, penulis menyarankan buat dosen untuk selalu menggunakan zoom clouds meeting dalam melaksanakan perkuliahan.

\section{KESIMPULAN}

Perkuliahan dengan menggunakan aplikasi zoom clouds meeting efektif dalam matakuliah termodinamika pemahaman konsep sistem termodinamika, persamaan keadaan, turunan parsial dalam termodinamika, hukum pertama termodinamika dan beberapa akibat dari hukum pertama termodinamika. Perkuliahan akan seperti sebenarnya tatap muka bila dosen mengoptimalkan semua fitur yang ada di zoom 
clouds meeting, sehingga disarankan kepada dosen dan mahasiswa mengoptimalkan pengunaan semua fitur dan fasilitas yang ada di zoom clouds meeting.

\section{UCAPAN TERIMA KASIH}

Terima kasih penulis sampaikan kepada FKIP Universitas Mataram dan Program Studi Pendidikan Fisika Universitas Mataram memberikan waktu, fasilitas dan kesempatan dalam melakukan penelitian ini. Alhamdulillah, puji dan syukur kami panjatkan kepada Allah SWT atas selesainya penelitian ini dan artikel yang menyertainya. Semoga penelitian ini, memberikan berkah buat mahasiswa, dosen dan pelaku-pelaku pendidikan lainnya.

\section{REFERENSI}

Arikunto, S., (2006). Dasar-Dasar Evaluasi Pendidikan. Jakarta: Bumi Aksara.

Ayub, S., (2020). Termodinamika untuk Guru. Mataram: Duta Pustaka Ilmu

Ayub, S., (2020). Termodinamika untuk Saintis. Mataram: Penerbit Einstein College

Arizona, K., Abidin, Z., \& Rumansyah (2020). Pembelajaran Online Berbasis Proyek Salah Satu Solusi Kegiatan Belajar Mengajar di Tengah Pandemi Covid-19: Jurnal JIPP, 5(1), 64-70, from https://doi.org/10.29303/jipp.v5i1.11 $\underline{1}$

Fraenkel, J.R., Wallen, N.E., \& Hyun, H.H. (2012). How To Design And Evaluate Research In Education (8th ed.). New York: McGraw-Hill

Hake, R.R., (1999). Analyzing change/gain scores.Retrieved from http://lists.asu.edu/cgibin/wa?A2=ind $9903 \& \mathrm{~L}=$ aera$\underline{\mathrm{d} \& \mathrm{P}=\mathrm{R} 6855}$ >

Klinger, Walter (1997). Survei Metode Pengajaran dalam Ilmu Pengetahuan Alam. Erziehungswiss, Fakultat der Universtat, Erlangen-Nurnbe
Ismawati, D. \& Prasetyo, I. (2020). Efektivitas Pembelajaran Menggunakan Video Zoom Cloud Meeting pada Anak Usia Dini Era Pandemi Covid-19: Jurnal Obsesi. 5(1). 665-675. from https://doi.org/10.31004/obsesi.v5i1.671

Monica, J. \& Fitriawati, D. (2020). Efektivitas Penggunaan Aplikasi Zoom Sebagai Media Pembelajaran Online Pada Mahasiswa Saat Pandemi Covid-19: Jurnal Communio. 9(2). 1630-1640. From https://doi.org/10.35508/jikom.v9i2.2 $\underline{416}$

Mulya, R. (2020). Pengembangan Perangkat Pembelajaran Model Reasoning and Problem Solving untuk Meningkatkan Kemampuan Pemecahan Masalah Fisika Peserta Didik. S1 Skripsi. Universitas Mataram.

Robandi, D., Darmansyah, \& Yeni, F. J. (2020). Efektifitas Penggunaan Aplikasi Zoom sebagai Media Pembelajaran Masa Pandemi Covid-19 di Kampus IPDN Sumatera Barat: Jurnal E-Tech, 8(2), 1-4, from https://doi.org/10.24036/et.v8i2.110957

Rizaldi, R., D. \& Fatimah, Z. (2020). Penggunaan Aplikasi Zoom Clouds Meeting pada Matakuliah Mekanika dan Termostatika saat Pandemi Covid-19: Jurnal Kappa, $4(2), \quad 225-232$, from https://ejournal.hamzanwadi.ac.id/index.php/kpj/a rticle/view/2237

Slameto. (2010). Belajar dan Faktor-Faktor yang Mempengaruhinya. Jakarta: Rineka Cipta.

Tekno \& Sains (2020). Bekerja di Rumah via Zoom Clouds Meeting. https://kumparan.com/berita-hariini/bekerja-di-rumah-via-zoom-cloudmeetings-berikut-cara-penggunaannya1t32UTTaqfP/full 